\title{
Microbacterium sediminicola sp. nov. and Microbacterium marinilacus sp. nov., isolated from marine environments
}

\author{
Akiko Kageyama, ${ }^{1}$ Yoko Takahashi, ${ }^{1}$ Yoshihide Matsuo, ${ }^{2}$ Hiroaki Kasai, ${ }^{2}$ \\ Yoshikazu Shizuri $^{2}$ and Satoshi Ōmura ${ }^{1,3}$ \\ ${ }^{1}$ Kitasato Institute for Life Sciences, Kitasato University, 5-9-1 Shirokane, Minato-ku, Tokyo 108- \\ 8642, Japan \\ ${ }^{2}$ Marine Biotechnology Institute, 3-75-1 Heita, Kamaishi, Iwate 026-0001, Japan \\ ${ }^{3}$ The Kitasato Institute, 5-9-1 Shirokane, Minato-ku, Tokyo 108-8642, Japan
}

Correspondence

Yoko Takahashi

ytakaha@lisci.kitasato-u.ac.jp
The genus Microbacterium was first proposed by OrlaJensen (1919) with the type species Microbacterium lacticum, and was emended by Takeuchi \& Hatano (1998). Members of the genus Microbacterium are Grampositive, obligately aerobic and catalase-positive. The peptide subunit of peptidoglycan consists of alanine, Dglutamic acid (plus hydroxyglutamic acid), and either Llysine, L-ornithine or L-homoserine. Menaquinones are MK-10, MK-11, MK-12, MK-13 and MK-14. Muramic acid occurs in the $N$-glycolyl form. The $\mathrm{G}+\mathrm{C}$ content of the genomic DNA ranges from 66 to $72 \mathrm{~mol} \%$. Members of the genus Microbacterium are widespread and can be isolated from various environmental habitats (Collins \& Bradbury, 1992). The genus Microbacterium is a member of the family Microbacteriaceae of the order Actinomycetales.

\footnotetext{
The GenBank/EMBL/DDBJ accession numbers for the 16S rRNA gene

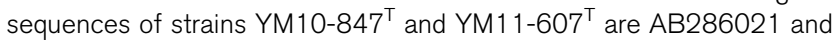
AB286020, respectively.

A phylogenetic tree based on $16 \mathrm{~S}$ rRNA gene sequences of all species of the genus Microbacterium and the composition of the medium ' $\mathrm{HO} .3$ ' are available as supplementary material with the online version of this paper.
}

Strain YM10-847 $7^{\mathrm{T}}$ was isolated from a sediment sample collected from the mouth of the Samambula River, Fiji (depth: $1 \mathrm{~m}$; GPS location: $18^{\circ} 7^{\prime} 14^{\prime \prime} \mathrm{S}, 178^{\circ} 28^{\prime} 18^{\prime \prime} \mathrm{E}$ ), in December 2003. Strain YM11-607 ${ }^{\mathrm{T}}$ was isolated from an unidentified hydroid collected from the Sano Marine Lake, Republic of Palau (depth: 1 m; GPS location: $07^{\circ} 17^{\prime} 74^{\prime \prime} \mathrm{N}$, $\left.134^{\circ} 26^{\prime} 92^{\prime \prime} \mathrm{E}\right)$, in March 2004. The samples $\left(0.5-1.0 \mathrm{~cm}^{3}\right)$ were homogenized with a glass rod in $5 \mathrm{ml}$ sterile seawater. Bacteria were isolated from the homogenate $(50 \mu \mathrm{l})$ by culturing at $25{ }^{\circ} \mathrm{C}$ for 30 days on $\mathrm{P}\left(\mathrm{YM} 10-847^{\mathrm{T}}\right)$ or $\mathrm{H} 0.3$ $\left(\mathrm{YM} 11-607^{\mathrm{T}}\right)$ media. Compositions of medium $\mathrm{P}$ were described in Yoon et al. (2007) and compositions of medium $\mathrm{H} 0.3$ are listed in Supplementary material available in IJSEM Online.

Biomass for biochemical and chemotaxonomic characteristics was prepared by culturing in TSB broth at $27^{\circ} \mathrm{C}$.

Morphological observation under a scanning electron microscope (model JSM-5600; JEOL) was performed using cultures grown on glucose-peptone meat extract agar medium ( $1 \%$ D-glucose, $0.5 \%$ peptone, $0.5 \%$ meat extract, $0.3 \% \mathrm{NaCl}$ and $1.2 \%$ agar; $\mathrm{pH} 7.0$ ) at $27{ }^{\circ} \mathrm{C}$ for 3 days. The carbon-assimilation properties of the two strains and three related species were determined by using a 
yeast nitrogen-based agar medium without amino acids (Nihon Pharmaceutical) (Pridham \& Gottlieb, 1948). NaCl tolerance, $\mathrm{pH}$ and temperature ranges for growth were determined on 1/5 nutrient agar or marine agar (Difco). The two isolated strains and type strains of the three related species were characterized biochemically using API ZYM (bioMérieux) in accordance with the manufacturer's instructions.

The $N$-acyl types of muramic acid were determined by using the method of Uchida \& Aida (1977). Cell walls were purified by using the method of Kawamoto et al. (1981). One milligram of purified cell wall was hydrolysed at $100{ }^{\circ} \mathrm{C}$ with $1 \mathrm{ml} 6 \mathrm{M} \mathrm{HCl}$ for $16 \mathrm{~h}$. The residue was dissolved in $100 \mu \mathrm{l}$ water and was used for amino acid analysis. The amino acid composition was determined by HPLC using the Pico Tag method (Waters). Samples were derivatized with phenylisothyocyanate and UV (254 nm) detection was used. The presence of mycolic acid was determined by using the TLC method described in Tomiyasu (1982). Menaquinones were extracted and purified by using the method described in Collins et al. (1977), and were then analysed by HPLC (model 802-SC; Jasco) using a chromatograph equipped with a Capcell Pak C18 column (Shiseido) (Tamaoka et al., 1983). Methyl esters of cellular fatty acids were prepared and analysed by GLC (model HP6890; Hewlett Packard).

DNA was isolated as described by Saito \& Miura (1963). DNA base composition was estimated by HPLC (Tamaoka \& Komagata, 1984). Levels of DNA-DNA relatedness were determined by the method of Ezaki et al. (1989) using photobiotin and a microplate format.

DNA was prepared using InstaGene matrix (Bio-Rad). The 16S rRNA gene was amplified by PCR using a forward primer corresponding to positions 8-27 and a reverse primer corresponding to positions 1492-1510 (Escherichia coli numbering system; Weisburg et al., 1991) and sequenced with an automated sequence analyser (3730 DNA Analyser; Applied Biosystems) using BigDye Terminator v3.1 Cycle Sequencing kit (Applied
Biosystems). Species related to the novel strains were identified by performing sequence database searches using the BLAST program (Altschul et al., 1990). Sequence data for related species were retrieved from GenBank. The CLUSTAL_X software (Thompson et al., 1997) was used for a multiple alignment of nucleotide sequences. Neighbourjoining (Saitou \& Nei, 1987) and maximum-parsimony analyses were conducted using MEGA version 3.1 (Kumar et al., 2004). Nucleotide substitution rates ( $K_{\text {nuc }}$ values) were calculated (Kimura \& Ohta, 1972) for the neighbourjoining method. Min-mini algorithm (Nei \& Kumar, 2000) was used for the maximum-parsimony method. The maximum-likelihood tree was inferred by using PHYML (Guindon \& Gascuel, 2003; Guindon et al., 2005). The distance-based tree was used as a starting tree to be refined by the maximum-likelihood algorithm based on the HKY model (Hasegawa et al., 1985), with a transition/transversion ratio and a gamma shape parameter, which were estimated by maximizing the likelihood of the phylogeny.

The 1465 and $1472 \mathrm{bp}$ of 16S rRNA gene sequences were determined for YM1 $1-607^{\mathrm{T}}$ and $\mathrm{YM} 10-847^{\mathrm{T}}$, respectively. Subsequent $16 \mathrm{~S}$ rRNA-based phylogenetic analysis demonstrated that the strains affiliated with the genus Microbacterium as shown in Supplementary Fig. S1 (available in IJSEM Online). YM11-60 $7^{\mathrm{T}}$ was closely related to Microbacterium paludicola in three kinds of trees (Figs 1, 2 and 3). The level of sequence similarity between YM11$607^{\mathrm{T}}$ and M. paludicola was $98.3 \%$. YM10-847 ${ }^{\mathrm{T}}$ was closely related to Microbacterium arborescens, Microbacterium imperiale and Microbacterium ulmi (Figs 1, 2 and 3). The level of sequence similarity between $\mathrm{YM} 10-847^{\mathrm{T}}$ and related Microbacterium species: $M$. arborescens, M. imperiale and M. ulmi was 98.3, 98.1 and $97.2 \%$, respectively.

The DNA G + C content of strains YM10-847 ${ }^{\mathrm{T}}$ and YM11$607^{\mathrm{T}}$ was 67.8 and $71.6 \mathrm{~mol} \%$, respectively. The cell-wall peptidoglycans of both strains contained L-ornithine as the diagnostic diamino acid. The major menaquinones were MK-10 and MK-11 for YM10-847 ${ }^{\mathrm{T}}$, and MK-11 and MK12 for YM11-607 ${ }^{\mathrm{T}}$. The acyl type of the peptidoglycans was

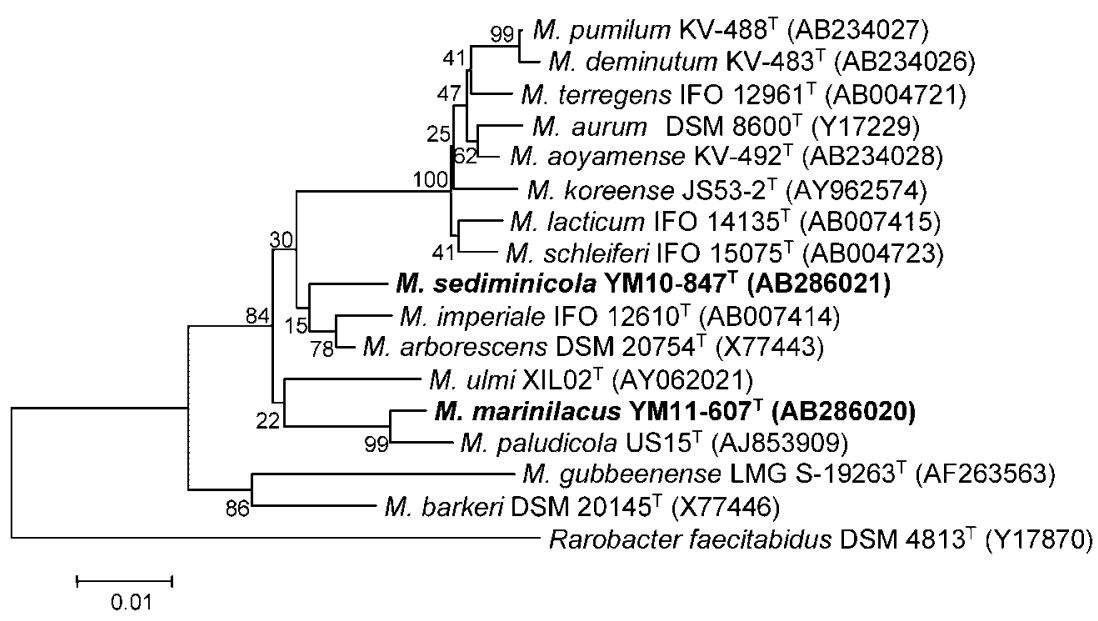

Fig. 1. Phylogenetic tree based on $16 \mathrm{~S}$ rRNA gene sequences and constructed using the neighbour-joining method and $K_{\text {nuc }}$ values. Numbers at branching points are bootstrap values (1000 resamplings). Rarobacter faecitabidus DSM $4813^{\top}$ was used as an outgroup. Bar, 1 substitution per $100 \mathrm{nt}$. 


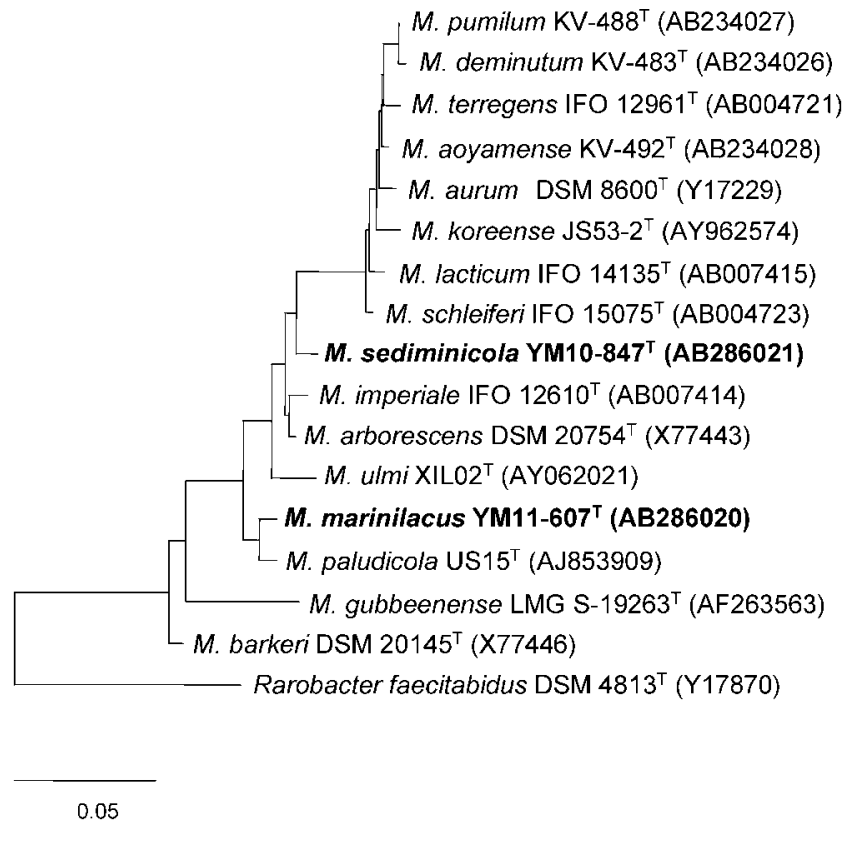

Fig. 2. Phylogenetic tree based on $16 \mathrm{~S}$ rRNA gene sequences and constructed using the maximum-likelihood method. Rarobacter faecitabidus DSM $4813^{\top}$ was used as an outgroup.

$\mathrm{N}$-glycolyl. The major cellular fatty acids were anteiso$\mathrm{C}_{15: 0}$, anteiso- $\mathrm{C}_{17: 0}$ and iso- $\mathrm{C}_{16: 0}$ (Table 1). These characteristics were well matched to the genus description of Microbacterium.

DNA-DNA relatedness was determined twice. Species with high $16 \mathrm{~S}$ rRNA sequence similarity values to the isolated strains were used for this experiment. Representative values for $\mathrm{YM} 10-847^{\mathrm{T}}$ and $M$. arborescens was $13 \%, \mathrm{YM} 10-847^{\mathrm{T}}$ and $M$. imperiale was $14 \%$, and $\mathrm{YM} 11-607^{\mathrm{T}}$ and $M$. paludicola was $36 \%$. These values are well below the $70 \%$ cut-off point for species classification, as recommended by Wayne et al. (1987), thus confirming that the isolated strains are two independent novel species of the genus Microbacterium.

The chemotaxonomic and morphological characteristics (Tables 1 and 2) of these two isolated strains are consistent with their assignment to the genus Microbacterium (Takeuchi \& Hatano, 1998). The phenotypes and characteristics that distinguish the isolated strains from one another and from their phylogenetic neighbours are listed in Table 2.

On the basis of the present results, we propose two novel Microbacterium species: Microbacterium sediminicola sp. nov. and Microbacterium marinilacus sp. nov.

\section{Description of Microbacterium sediminicola sp. nov.}

Microbacterium sediminicola (sedi.mi.ni.co'la. L. n. sedimen -inis, sediment; L. suff. -cola, inhabitant dweller; N.L. n. sediminicola, sediment-dweller).

Cells are rod-shaped, vary in cell size from 0.4 to 0.7 by 0.8 to $1.5 \mu \mathrm{m}$. Gram-positive, catalase-positive, aerobic. Colonies are pale yellow. Growth occurs between $\mathrm{pH} 6$ and 11 , and 19 and $38^{\circ} \mathrm{C}$. In $1 / 5$ nutrient agar medium, $\mathrm{NaCl}$ is tolerated up to $7 \%$. L-Arabinose, D-galactose, D-glucose, maltose, D-mannitol, D-mannose, L-rhamnose, trehalose and D-xylose are assimilated, but D-fructose, raffinose and sucrose are not. Esterase (C4), esterase lipase (C8), leucine arylamidase, valine arylamidase, cystine arylamidase, acid phosphatase, $\alpha$-galactosidase, $\beta$-galactosidase, $\alpha$-glucosidase, $\beta$-glucosidase, $N$-acetyl- $\beta$-glucosaminidase are detected by the API ZYM enzyme assay; alkaline phosphatase, chymotrypsin, naphthol-AS-BI-phosphohydrolase, $\beta$-glucuronidase, $\alpha$-mannosidase and $\alpha$-fucosidase are negative. Weak reaction for lipase (C14) and trypsin is detected. The acyl type of the peptidoglycan was $\mathrm{N}$ glycolyl. The major menaquinones are MK-10 and MK-11. The major cellular fatty acids are anteiso- $\mathrm{C}_{15: 0}$, anteiso- $\mathrm{C}_{17: 0}$ and iso- $\mathrm{C}_{16: 0}$. The DNA G+C content is $67.8 \mathrm{~mol} \%$.

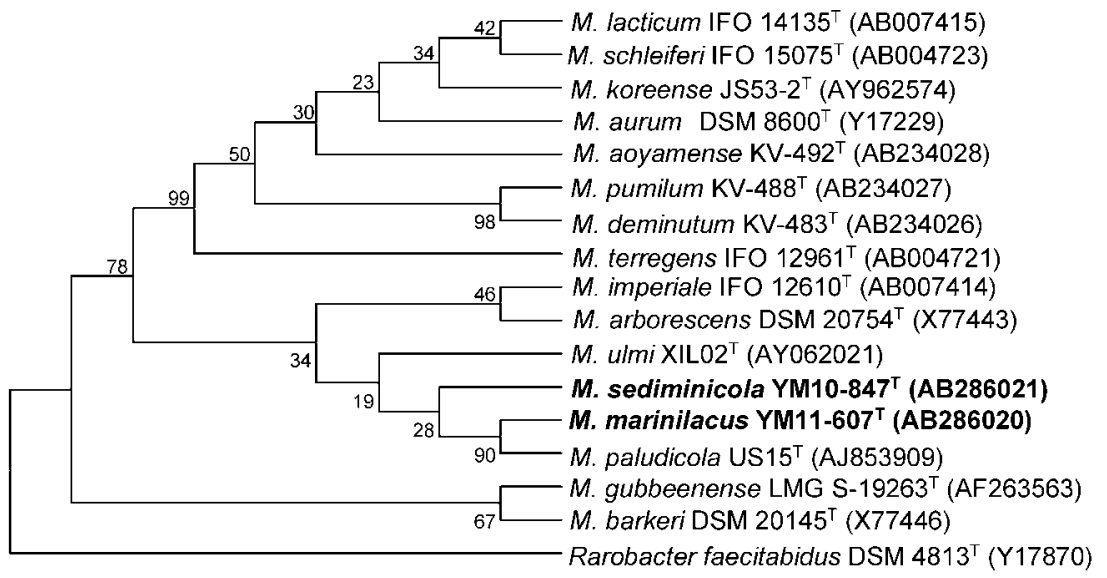

Fig. 3. Phylogenetic tree based on $16 \mathrm{~S}$ rRNA gene sequences and constructed using the maximum-parsimony method. Numbers at branching points are bootstrap values (100 resamplings). Rarobacter faecitabidus DSM $4813^{\top}$ was used as an outgroup. Bar, 5 substitution per $100 \mathrm{nt}$. 
Table 1. Fatty acid composition (\%) of isolated strains

\begin{tabular}{|c|c|c|}
\hline Fatty acid & YM10-847 & YM11-607 ${ }^{\mathrm{T}}$ \\
\hline iso- $\mathrm{C}_{14: 0}$ & 1.42 & 2.03 \\
\hline iso- $\mathrm{C}_{15: 0}$ & - & 2.08 \\
\hline anteiso- $\mathrm{C}_{15: 0}$ & 40.63 & 59.11 \\
\hline iso- $\mathrm{C}_{16: 0}$ & 24.85 & 14.37 \\
\hline anteiso- $\mathrm{C}_{17: 0}$ & 31.93 & 20.91 \\
\hline
\end{tabular}

The type strain, YM10-847 ${ }^{\mathrm{T}} \quad\left(=\mathrm{MBIC} 08264^{\mathrm{T}}=\mathrm{DSM}\right.$ $18905^{\mathrm{T}}$ ), was isolated from sediment collected from the mouth of the Samambula River, Fiji.

\section{Description of Microbacterium marinilacus sp. nov.}

Microbacterium marinilacus (mari.ni.la'cus. L. adj. marinus, marine; L. n. lacus -us, lake; N.L. gen. n. marinilacus, of a marine lake).

Cells are rod-shaped, vary in cell size from 0.4 to 0.6 by 0.9 to $1.4 \mu \mathrm{m}$. Gram-positive, catalase-positive, aerobic.
Colonies are lemon yellow. Growth occurs between $\mathrm{pH} 6$ and 11 , and 12 and $38{ }^{\circ} \mathrm{C}$. In $1 / 5$ nutrient agar medium, $\mathrm{NaCl}$ is tolerated up to $8 \%$. L-Arabinose, D-fructose, Dglucose, maltose, D-mannitol, D-mannose, L-rhamnose, trehalose and D-xylose are assimilated, but D-galactose, raffinose and sucrose are not. Esterase (C4), esterase lipase (C8), leucine arylamidase, valine arylamidase, cystine arylamidase, trypsin, naphthol-AS-BI-phosphohydrolase, $\alpha$-glucosidase, $\beta$-glucosidase, $N$-acetyl- $\beta$-glucosaminidase and $\alpha$-fucosidase are detected by the API ZYM enzyme assay; alkaline phosphatase, $\alpha$-galactosidase, $\beta$-galactosidase, $\beta$-glucuronidase and $\alpha$-mannosidase are negative. Weak reaction for lipase (C14), chymotrypsin, acid phosphatase and trypsin is detected. The acyl type of the peptidoglycan was $N$-glycolyl. The major menaquinones are MK-11 and MK-12. The major cellular fatty acids are anteiso- $\mathrm{C}_{15: 0}$, anteiso- $\mathrm{C}_{17: 0}$ and iso- $\mathrm{C}_{16: 0}$. The DNA G +C content is $71.6 \mathrm{~mol} \%$.

The type strain, YM11-607 ${ }^{\mathrm{T}} \quad\left(=\right.$ MBIC07778 ${ }^{\mathrm{T}}=\mathrm{DSM}$ $\left.18904^{\mathrm{T}}\right)$, was isolated from an unidentified hydroid collected from the Sano Marine Lake, Republic of Palau.

Table 2. Differential characteristics between the isolated strains and related Microbacterium species

Strain/species: 1, YM10-847 ${ }^{\mathrm{T}}$; 2, YM11-607 ${ }^{\mathrm{T}}$; 3, M. paludicola; 4, M. arborescens; 5, M. imperiale; 6, M. ulmi. Data for the type strains of M. paludicola, M. arborescens, M. imperiale and M. ulmi regarding API ZYM tests and assimilation of carbon sources are from the present study. Other data on M. imperiale and M. arborescens are from Behrendt et al. (2001) and Takeuchi \& Hatano (1998), respectively, other data on M. paludicola are from Park et al. (2006), and other data on M. ulmi are from Rivas et al. (2004). +, Positive; -, negative; W, weakly positive; ND, no data; Orn, Lornithine; Lys, L-lysine.

\begin{tabular}{|c|c|c|c|c|c|c|}
\hline Characteristic & 1 & 2 & 3 & 4 & 5 & 6 \\
\hline Growth at $37^{\circ} \mathrm{C}$ & + & + & + & - & + & + \\
\hline Colony colour & Pale yellow & Lemon yellow & Lemon yellow & Dirty orange & Red-orange & White \\
\hline \multicolumn{7}{|l|}{ Assimilation of: } \\
\hline L-Arabinose & + & + & + & + & + & - \\
\hline D-Fructose & - & + & + & + & + & + \\
\hline D-Galactose & + & - & + & + & + & + \\
\hline D-Mannitol & + & + & + & + & + & - \\
\hline Raffinose & - & - & + & + & + & - \\
\hline L-Rhamnose & + & + & + & + & + & - \\
\hline Sucrose & - & - & + & + & + & - \\
\hline D-Xylose & + & + & + & + & + & - \\
\hline \multicolumn{7}{|l|}{ Enzyme assay (API ZYM): } \\
\hline Alkaline phosphatase & - & - & - & + & + & + \\
\hline Trypsin & $\mathrm{W}$ & + & + & + & + & - \\
\hline Chymotrypsin & - & $\mathrm{W}$ & $\mathrm{W}$ & + & + & - \\
\hline Naphthol-AS-BI-phosphohydrolase & - & + & + & $\mathrm{W}$ & $\mathrm{w}$ & + \\
\hline$\alpha$-Galactosidase & + & - & - & + & + & - \\
\hline$\beta$-Galactosidase & + & - & - & + & + & + \\
\hline$N$-Acetyl- $\beta$-glucosaminidase & + & + & - & + & + & + \\
\hline$\alpha$-Mannosidase & - & - & + & + & + & - \\
\hline$\alpha$-Fucosidase & - & + & - & - & - & - \\
\hline $\mathrm{pH}$ range & $6-11$ & $6-11$ & $6-8$ & ND & ND & $5-8$ \\
\hline DNA G $+C$ content $(\mathrm{mol} \%)$ & 67.8 & 71.6 & 66.5 & 71.0 & 71.2 & 69.0 \\
\hline Cell wall diamino acid & Orn & Orn & Orn & Lys & Lys & Orn \\
\hline Major menaquinones (MK) & 10,11 & 11,12 & 11,12 & 11,12 & 11,12 & $11,12,13$ \\
\hline
\end{tabular}




\section{Acknowledgements}

This study was supported in part by a Grant of the 21st Century COE Program from the Ministry of Education, Culture, Sports, Science and Technology (MEXT) and the JSPS Grant-in-Aid for Science Research foundation. This work was in part supported by New Energy and Industrial Technology Development Organization (NEDO).

\section{References}

Altschul, S. F., Gish, W., Miller, W., Myers, E. W. \& Lipman, D. J. (1990). Basic local alignment search tool. J Mol Biol 215, 403-410.

Behrendt, U., Ulrich, A. \& Schumann, P. (2001). Description of Microbacterium foliorum sp. nov. and Microbacterium phyllosphaerae sp. nov., isolated from the phyllosphere of grasses and the surface litter after mulching the sward, and reclassification of Aureobacterium resistens (Funke et al. 1998) as Microbacterium resistens comb. nov. Int J Syst Evol Microbiol 51, 1267-1276.

Collins, M. D. \& Bradbury, J. F. (1992). The genera Agromyces, Aureobacterium, Clavibacter, Curtobacterium, and Microbacterium. In The Prokaryotes, pp. 1355-1368. Edited by A. Balows, H. G. Truper, M. Dworkin, W. Harder \& K.-H. Schleifer. Berlin: Springer.

Collins, M. D., Pirouz, T., Goodfellow, M. \& Minnikin, D. E. (1977). Distribution of menaquinones in actinomycetes and corynebacteria. $J$ Gen Microbiol 100, 221-230.

Ezaki, T., Hashimoto, Y. \& Yabuuchi, E. (1989). Fluorometric deoxyribonucleic acid-deoxyribonucleic acid hybridization in microdilution wells as an alternative to membrane filter hybridization in which radioisotopes are used to determine genetic relatedness among bacterial strains. Int J Syst Bacteriol 39, 224-229.

Guindon, S. \& Gascuel, O. (2003). A simple, fast and accurate algorithm to estimate large phylogenies by maximum likelihood. Syst Biol 52, 696-704.

Guindon, S., Lethiec, F., Duroux, P. \& Gascuel, O. (2005). PHYML Online-a web server for fast maximum likelihood-based phylogenetic inference. Nucleic Acids Res 33 (Web Server issue), W557-W559.

Hasegawa, M., Kishino, H. \& Yano, T. (1985). Dating of the humanape splitting by a molecular clock of mitochondrial DNA. J Mol Evol 22, 160-174.

Kawamoto, I., Oka, T. \& Nara, T. (1981). Cell wall composition of Micromonospora olivoasterospora, Micromonospora sagamiensis, and related organisms. J Bacteriol 146, 527-534.

Kimura, M. \& Ohta, T. (1972). On the stochastic model for estimation of mutation distance between homologous proteins. J Mol Evol 2, 87-90.

Kumar, S., Tamura, K. \& Nei, M. (2004). MEGA3: Integrated software for Molecular Evolutionary Genetics Analysis and sequence alignment. Brief Bioinform 5, 150-163.

Nei, M. \& Kumar, S. (2000). Phylogenetic inference: maximum parsimony methods. In Molecular Evolution and Phylogenetics, pp. 115-146. New York: Oxford University Press.
Orla-Jensen, S. (1919). The Lactic Acid Bacteria. Copenhagen: Host \& Sons.

Park, H. Y., Kim, K. K., Jin, L. \& Lee, S. T. (2006). Microbacterium paludicola sp. nov., a novel xylanolytic bacterium isolated from swamp forest. Int J Syst Evol Microbiol 56, 535-539.

Pridham, T. G. \& Gottlieb, D. (1948). The utilization of carbon compounds by some Actinomycetales as an aid for species determination. J Bacteriol 56, 107-114.

Rivas, R., Trujillo, M. E., Sanchez, M., Mateos, P. F., Martinez-Molina, E. \& Velazquez, E. (2004). Microbacterium ulmi sp. nov., a xylanolytic, phosphate-solubilizing bacterium isolated from sawdust of Ulmus nigra. Int J Syst Bacteriol 54, 513-517.

Saito, H. \& Miura, K. (1963). Preparation of transforming deoxyribonucleic acid by phenol treatment. Biochim Biophys Acta 72, 619-629.

Saitou, N. \& Nei, M. (1987). The neighbor-joining method: a new method for reconstructing phylogenetic trees. Mol Biol Evol 4, 406-425.

Takeuchi, M. \& Hatano, K. (1998). Union of the genera Microbacterium Orla-Jensen and Aureobacterium Collins et al. in a redefined genus Microbacterium. Int J Syst Bacteriol 48, 739-747.

Tamaoka, J. \& Komagata, K. (1984). Determination of DNA base composition by reversed-phase high-performance liquid chromatography. FEMS Microbiol Lett 25, 125-128.

Tamaoka, J., Katayama-Fujimura, Y. \& Kuraishi, H. (1983). Analysis of bacterial menaquinone mixtures by high performance liquid chromatography. J Appl Bacteriol 54, 31-36.

Thompson, J. D., Gibson, T. J., Plewniak, F., Jeanmougin, F. \& Higgins, D. G. (1997). The CLUSTAL_X windows interface: flexible strategies for multiple sequence alignment aided by quality analysis tools. Nucleic Acids Res 25, 4876-4882.

Tomiyasu, I. (1982). Mycolic acid composition and thermally adaptive changes in Nocardia asteroides. J Bacteriol 151, 828-837.

Uchida, K. \& Aida, K. (1977). Acyl type of bacterial cell wall: its simple identification by a colorimetric method. J Gen Appl Microbiol 23, 249-260.

Wayne, L. G., Brenner, D. J., Colwell, R. R., Grimont, P. A. D., Kandler, O., Krichevsky, M. I., Moore, L. H., Moore, W. E. C., Murray, R. G. E. \& other authors (1987). International Committee on Systematic Bacteriology. Report of the ad hoc committee on reconciliation of approaches to bacterial systematics. Int J Syst Bacteriol 37, 463-464.

Weisburg, W. G., Barns, S. M., Pelletier, D. A. \& Lane, D. J. (1991). 16S ribosomal DNA amplification for phylogenetic study. J Bacteriol 173, 697-703.

Yoon, J., Yasumoto-Hirose, M., Matsuo, Y., Nozawa, M., Matsuda, S., Kasai, H. \& Yokota, A. (2007). Pelagicoccus mobilis gen. nov., sp. nov., Pelagicoccus albus sp. nov. and Pelagicoccus litoralis sp. nov., three novel members of subdivision 4 within the phylum 'Verrucomicrobia' isolated from seawater by in situ cultivation. Int J Syst Evol Microbiol 57, 1377-1385. 